\title{
EFFECTS OF E-LEARNING AS A TEACHING LEARNING METHOD IN MEDICAL EDUCATION
}

\author{
Saritha J. Shenoy ${ }^{1}$, Chitra Kuriakose ${ }^{2}$ \\ ${ }_{1}^{1}$ Assistant Professor, Department of Physiology, Government Medical College, Kottayam. \\ ${ }^{2}$ Assistant Professor, Department of Physiology, Government Medical College, Kottayam.
}

ABSTRACT

\section{BACKGROUND}

According to the new curriculum, the duration of First MBBS has been reduced to one year and faculty was finding it difficult to complete the syllabus in prescribed time. This project explores the efficacy of E-Learning and an additional teaching learning method along with conventional methods.

The objectives of this study is to measure the effects of E-learning in medical education.

\section{MATERIALS AND METHODS}

An E-learning module was created on four selected topics. Students were randomly divided into two groups and two separate Google groups were created. Both groups were exposed to E-Learning and conventional lecture. Student's perception on E-learning was assessed by questionnaire method and performance by post-test.

\section{RESULTS}

72.8\% liked E-Learning as an additional tool and 95.2\% commented that it should be included in the curriculum $71.4 \%$ were accessing internet through mobiles; $28.6 \%$ commented they liked it to obtain complete notes and another $28.6 \%$ because of asynchronous access; $38.1 \%$ commented there was no direct contact with the faculty and $32.7 \%$ about poor access to internet. The mean mark for E-Learning post-test was 15.8 and lecture was 13.9, which were found to be statistically significant.

\section{CONCLUSION}

E-Learning as a teaching learning method produced statistically significant difference in post-test marks compared to conventional method and was liked by $72.8 \%$ students.

\section{KEYWORDS}

E-Learning, Teaching Learning Method, First MBBS Students.

HOW TO CITE THIS ARTICLE: Shenoy SJ, Kuriakose C. Effects of E-learning as a teaching learning method in medical education. J. Evolution Med. Dent. Sci. 2016;5(99):7272-7275, DOI: 10.14260/jemds/2016/1645

\begin{abstract}
BACKGROUND
The education systems are undergoing major changes all over the world with educational courses and programs being designed in new ways accompanied by new educational contents to incorporate the most updated knowledge to pave the way for making use of new technological advances.(1) Elearning is the use of Internet technologies to enhance knowledge and performance. E-learning technologies offer learners control over content, learning sequence, pace of learning, time and often media allowing them to tailor their experiences to meet their personal learning objectives. In diverse medical education contexts, E-learning appears to be at least as effective as traditional instructor-led methods such as lectures.(2-5) Students do not see E-learning as replacing traditional instructor-led training, but as a complement to it forming part of a blended-learning strategy.
\end{abstract}

Financial or Other, Competing Interest: None.

Submission 31-10-2016, Peer Review 01-12-2016,

Acceptance 07-12-2016, Published 12-12-2016.

Corresponding Author:

Dr. Saritha J. Shenoy,

Assistant Professor

Department of Physiology,

Government Medical College,

Kottayam-686008, Kerala.

E-mail: ajaikamathsaritha@gmail.com

DOI: $10.14260 /$ jemds $/ 2016 / 1645$
A developing infrastructure to support E-learning within medical education includes repositories or digital libraries to manage access to E-learning materials, consensus on technical standardisation and methods for peer review of these resources.(6) E-Learning presents numerous research opportunities for faculty along with continuing challenges for documenting scholarship. Innovations in E-Learning technologies point toward a revolution in education allowing learning to be individualised (adaptive learning), enhancing learners' interactions with others (Collaborative learning) and transforming the role of the teacher. The integration of $\mathrm{E}$ Learning into medical education can catalyse the shift toward applying adult learning theory, where educators will no longer serve mainly as the distributors of content but will become more involved as facilitators of learning and assessors of competency.(7) Today's medical educators have different challenges compared to previous generation in teaching tomorrow's physicians. In the recent times, rapid changes in health care delivery system and advances in medicine have increased demands on academic faculty resulting in less time for teaching than has previously been the case.(8-9) The students engaged in E-Learning activities will be able to construct their own knowledge through self-directed learning. Eventually performance of the students may increase by implementation of E-Learning at various medical colleges in India.(10-11) 


\section{Objectives}

- To measure the effectiveness of E-learning in medical education.

- To assess the perception of students about E-learning as a teaching learning method.

\section{MATERIALS AND METHODS}

After obtaining permission from Institutional Review Board, an E-Learning module was created with help of colleagues in the Department of physiology on selected topics. Four different topics of same weightage were selected to avoid any mixing of study materials by the students. The topics selected were Physiology of coronary circulation, Physiology of cerebral circulation, Physiology of jugular venous pulse and Physiology of arterial pulse. A pilot study was conducted for the modules on randomly selected students.

\section{Study Design}

Interventional study.

\section{Study Setting}

First MBBS students in the Physiology Department, Govt. Medical College, Kottayam.

\section{Study Subjects}

Single group.

\section{Sample Size}

150 students.

\section{Sampling Methods}

Convenient sampling.

\section{Study Period}

2014 - 2015.

\section{Instrument}

Feedback, Post-test

After taking a written consent, the students were divided into two groups of 75 each by convenient sampling method. The platform chosen to deliver E-Learning was using Google groups. A new G-mail ID was created for all the students and two separate Google groups were created. Initially, first group was exposed to conventional lecture on coronary circulation and the second group was exposed to E-Learning on cerebral circulation. After a study period of one week, a post-test was conducted on respective topics. Next the process was repeated with the first group exposed to E-Learning on arterial pulse and second group to traditional lecture on jugular venous pulse. The students were crossed over to avoid ethical issues. All interactions with the students on the topics given through E-Learning were done through Google groups. After the posttest student's perception on E-Learning was assessed by a validated questionnaire.

\section{RESULTS}

A total of 147 students participated in the study. There were 95 female students and 52 male students. Unpaired ' $t$ ' test was used for analysis of post-test; the results of post-test is given (Table 1) below. The mean mark for E-Learning post-test was
15.8 and lecture was 13.9 , which were found to be statistically significant.

\begin{tabular}{|c|c|c|c|c|c|c|}
\hline & N & Mean & SD & $\begin{array}{c}\text { T } \\
\text { value }\end{array}$ & MD & Significance \\
\hline $\begin{array}{c}\text { E- } \\
\text { Learning }\end{array}$ & 147 & 15.813 & 3.1138 & 4.236 & 1.8299 & .000 \\
\hline Lecture & 147 & 13.983 & 4.2116 & & 1.8299 & .000 \\
\hline \multicolumn{6}{|c|}{ Table 1. Post-Test Results } \\
\hline
\end{tabular}

The feedback of students on E-Learning assessed by questionnaire was analysed by Chi square test; $72.8 \%$ liked ELearning as an additional tool and $95.2 \%$ commented that it should be included in the curriculum; $46.3 \%$ students accessed the facility while in hostel and $41.5 \%$ at home; $87.1 \%$ students were using E-Learning for academic and non-academic purpose (Table 2); 71.4\% were accessing internet through mobiles (Figure 1); $28.6 \%$ commented they liked it to obtain complete notes and another $28.6 \%$ because of asynchronous access (Figure 2); 38.1\% commented there was no direct contact with the faculty and $32.7 \%$ about poor access to internet (Figure 3); 35\% students commented that E-Learning be included in Physiology, 22\% physiology and biochemistry and $21 \%$ commented all three subjects should include it in their curriculum (Figure 4).

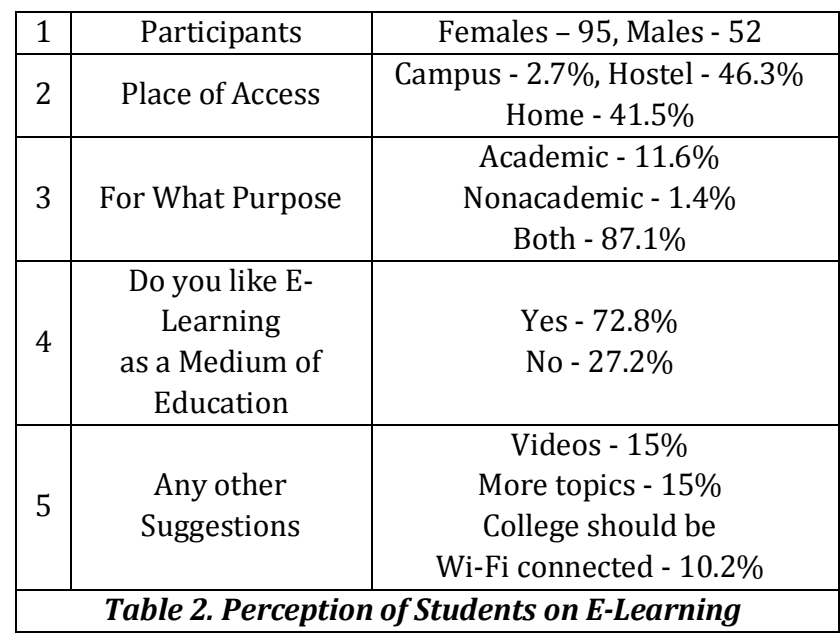

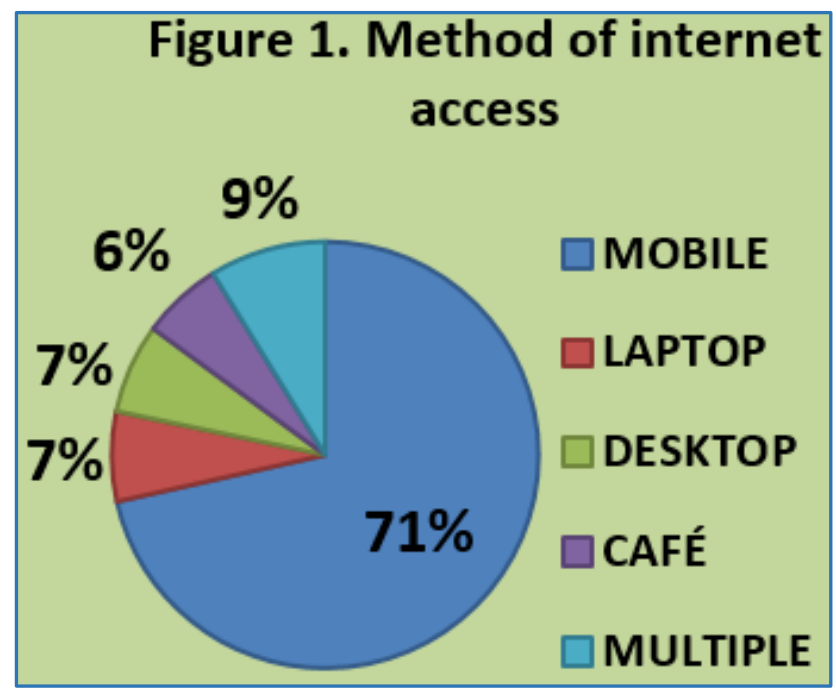



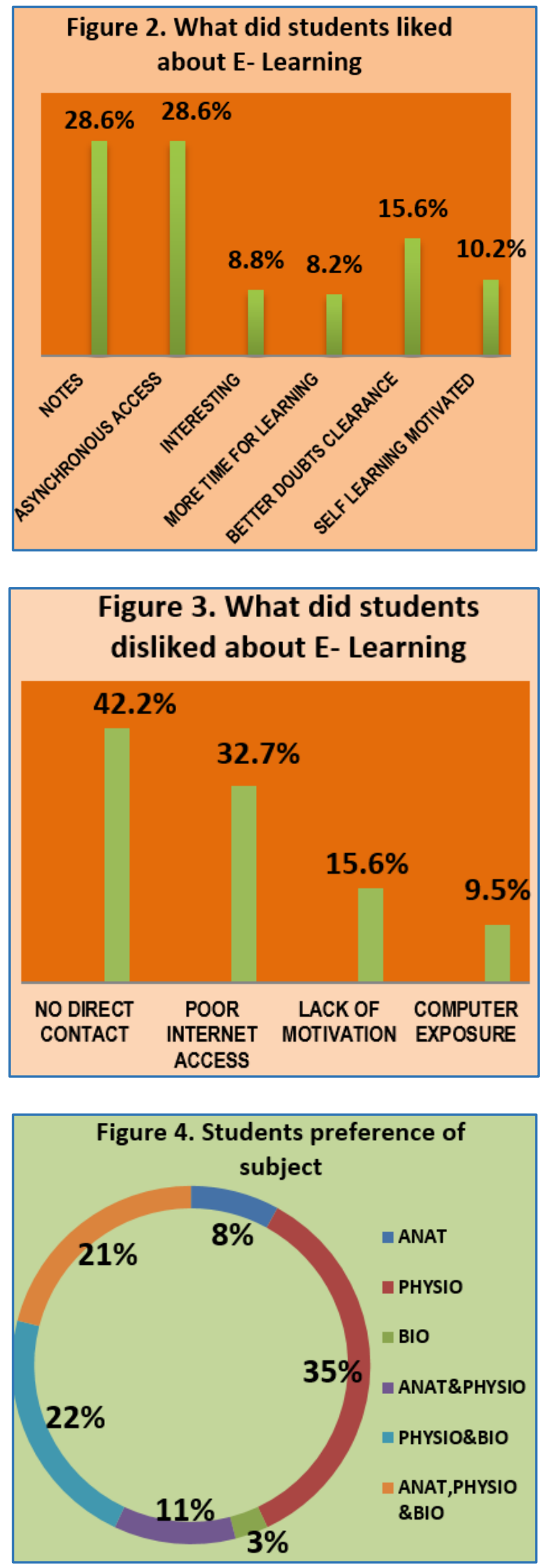

\section{DISCUSSION}

The need for increasing the number of health care professionals in developing countries and the difficulties in accomplishing this with limited faculty and institutional resources has been well-documented. Over the next several years, the question is not whether E-Learning will be a component of health education but rather what is E-Learning best used for within institutions, when and how to implement E-Learning successfully, and how we will ensure a beneficial effect on our learners and faculty.(12) It is expected that if India and developing countries proceed as joint venture and work mutually on the issue of E-Learning, it will be beneficial for the development of educational sector. Through E-Learning lot of opportunities can be captured and speedy developments will be possible.(13) With all the challenges that India is facing in education and training, E-Learning provides many answers and needs to be addressed seriously by the planners, developers and the private industry players. In the knowledge economy, the chief competitive advantage of nations is not their physical assets, be it land, natural resources or even oil, but quality and skill of their people. The revolution of ELearning has begun and is at an infant stage and needs to be nurtured further. We have to work hard to develop robust and flexible modules to explore the opportunities to greater heights.(14-16)

While E-Learning is defined as learning supported by digital electronic tools and media, M-Learning is defined as ELearning using mobile devices and wireless transmission. In the past several years, mobile learning made rapid inroads into the provision of medical education. There are significant advantages associated with mobile learning. These include high access, low cost, more situated and contextual learning, convenience for the learner, continuous communication and interaction between learner and tutor and between learner and other learners, and the ability to self-assess them while learning. Like any other form of medical pedagogy, mobile learning has its downsides. Disadvantages of mobile learning include: inadequate technology, a risk of distraction from learning by using a device that can be used for multiple purposes and the potential for breakdown in barriers between personal usage of the mobile device and professional or educational use. Despite these caveats, there is no question but that mobile learning offers much potential.(17-19)

At the end for anyone who questions, How could ELearning be beneficial in medical education? The answer is Video lectures would not replace the teachers, E-books would not replace libraries, simulation would not replace practical sessions, but for sure they will certainly make a supportive for themselves. Till now there is no standardisation to the quality of these course materials and course structure as well as nomenclature of these programs. Until this is done, we would have a long way to go before virtual learning could be used as additional method along with real time learning.(20)

\section{CONCLUSION}

The study concluded that E-Learning was well accepted by First MBBS students and statistically significant difference in marks was obtained in the post-test. In institution where faculty strength is a limitation, this can be used effectively as an additional tool along with conventional method. It also allows flexibility in student-teacher interactions. In the era of mobile phones, M-Learning is an easy and effective method through which E-Learning can be delivered.

\section{Acknowledgements}

This study is indebted to (i) MCI nodal Centre for Medical Education Technologies, Kottayam; (ii) Department of Physiology, Govt. Medical College, Kottayam; (iii) 2014 MBBS students Govt. Medical College, Kottayam. 


\section{REFERENCES}

1. Ghasemi N, Falsaafi P, Aminabadi NA, et al. Ayla Bahramian E-learning in medical sciences education: a comprehensive review. Indian Journal of research 2016;5:107-9.

2. Bridges $\mathrm{S}$, Chang JW, Chu $\mathrm{CH}$, et al. Blended learning in situated contexts: 3-year evaluation of an online peer review project. European journal of dental education: official journal of the association for dental education in Europe 2014;18(3):170-9.

3. Camargo LB, Raggio DP, Bonacina CF, et al. Proposal of Elearning strategy to teach atraumatic restorative treatment (ART) to undergraduate and graduate students. BMC research notes 2014;7:456.

4. Su ZY, Wu TY, Shieh TY, et al. Influence of dentistry students E-learning satisfaction: a questionnaire survey. Journal of medical systems 2011;35(6):1595-603.

5. Corum KA, Gadbury-Amyot CC, Johnson K, et al. U.S. dental hygiene faculty perceptions of learner outcomes in distance education courses. Journal of dental education 2014;78(4):530-40.

6. Davids MR, Chikte UM, Halperin ML. Effect of improving the usability of an E-learning resource: a randomized trial. Advances in physiology education 2014;38(2):15560.

7. El Tantawi MM, Abdelsalam MM, Mourady AM, et al. Eassessment in a limited-resources dental school using an open-source learning management system. Journal of dental education 2015;79(5):571-83.

8. Kadam SS, Wani P, Akhade S. E-learning for medical education in India: a review. Journal of Forensic Medicine Science and Law 2015;24(1):1-6.

9. Ozuah PO. Undergraduate medical education: thoughts on future challenges. BMC Med Educ 2002;2:8-10.
10. Rajendran PR. MSJAMA. The internet: ushering in a new era in of medicine. JAMA 2001;285(6):804.

11. Rajashree R, Parineeta P. MV Ravishankar effective use of E-learning in basic medical sciences. National Journal of Basic Medical Sciences 2014;2(4).

12. Frehywot $\mathrm{S}$, Vovides $\mathrm{Y}$, Talib Z, et al. E-learning in medical education in resource constrained low- and middleincome countries. Journal of Human Resource and Health 2013;11:4.

13. Gaikwad A, Randhir VS. E-learning in India: Wheel of Change. International Journal of e-Education, e-Business, e-Management and e-Learning 2016;6(1):40-5.

14. Rajpal S, Singh S, Bhardwaj A, et al. E-learning revolution: status of educational programs in India. IMECS 2008;1:19-21.

15. Abouchedid K, Eid GM. E-learning challenges in the Arab world: revelations from a case study profile. Quality Assurance in Education 2004;12(1):15-27.

16. Bagert DJ, Mu X. Current state of software engineering masters degree programs in the United Stated. Proceedings of the Frontiers in Education Conference Indianapolis, IN, USA 2005;3:9-22.

17. Walsh K. Mobile learning in medical education: review. Ethiop J Health Sci 2015;25(4):363-6.

18. Chatterley T, Chojecki D. Personal digital assistant usage among undergraduate medical students: exploring trends, barriers, and the advent of smartphones. Journal of the Medical Library Association 2010;98(2):157-60.

19. Prensky M. Digital natives, digital immigrants. On the Horizon 2001;9(5):1-6.

20. Hemalatha S. E-learning in health education-feasibility, pros and cons. International Journal of Advanced Research in Computer Science and Software Engineering $2015 ; 5(3)$. 